\title{
Front Matter: Volume 11681
}

, "Front Matter: Volume 11681," Proc. SPIE 11681, Physics, Simulation, and Photonic Engineering of Photovoltaic Devices X, 1168101 (20 April 2021); doi: $10.1117 / 12.2596589$

SPIE. Event: SPIE OPTO, 2021, Online Only 


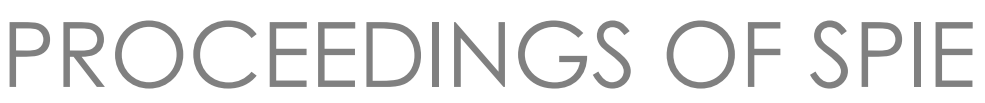

\section{Physics, Simulation, and Photonic Engineering of Photovoltaic Devices $X$}

Alexandre Freundlich

Stéphane Collin

Karin Hinzer

Editors

6-11 March 2021

Online Only, United States

Sponsored and Published by

SPIE

Volume 11681 
The papers in this volume were part of the technical conference cited on the cover and title page. Papers were selected and subject to review by the editors and conference program committee. Some conference presentations may not be available for publication. Additional papers and presentation recordings may be available online in the SPIE Digital Library at SPIEDigitalLibrary.org.

The papers reflect the work and thoughts of the authors and are published herein as submitted. The publisher is not responsible for the validity of the information or for any outcomes resulting from reliance thereon.

Please use the following format to cite material from these proceedings:

Author(s), "Title of Paper," in Physics, Simulation, and Photonic Engineering of Photovoltaic Devices $X$, edited by Alexandre Freundlich, Stéphane Collin, Karin Hinzer, Proceedings of SPIE Vol. 11681 (SPIE, Bellingham, WA, 2021) Seven-digit Article CID Number.

ISSN: 0277-786X

ISSN: 1996-756X (electronic)

ISBN: 9781510641976

ISBN: 9781510641983 (electronic)

Published by

SPIE

P.O. Box 10, Bellingham, Washington 98227-0010 USA

Telephone +1 3606763290 (Pacific Time) · Fax +1 3606471445

SPIE.org

Copyright (c) 2021, Society of Photo-Optical Instrumentation Engineers.

Copying of material in this book for internal or personal use, or for the internal or personal use of specific clients, beyond the fair use provisions granted by the U.S. Copyright Law is authorized by SPIE subject to payment of copying fees. The Transactional Reporting Service base fee for this volume is $\$ 21.00$ per article (or portion thereof), which should be paid directly to the Copyright Clearance Center (CCC), 222 Rosewood Drive, Danvers, MA 01923. Payment may also be made electronically through CCC Online at copyright.com. Other copying for republication, resale, advertising or promotion, or any form of systematic or multiple reproduction of any material in this book is prohibited except with permission in writing from the publisher. The CCC fee code is $0277-$ $786 \mathrm{X} / 21 / \$ 21.00$.

Printed in the United States of America by Curran Associates, Inc., under license from SPIE.

Publication of record for individual papers is online in the SPIE Digital Library.

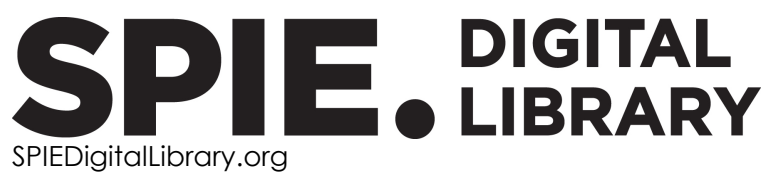

Paper Numbering: Proceedings of SPIE follow an e-First publication model. A unique citation identifier (CID) number is assigned to each article at the time of publication. Utilization of CIDs allows articles to be fully citable as soon as they are published online, and connects the same identifier to all online and print versions of the publication. SPIE uses a seven-digit CID article numbering system structured as follows:

- The first five digits correspond to the SPIE volume number.

- The last two digits indicate publication order within the volume using a Base 36 numbering system employing both numerals and letters. These two-number sets start with $00,01,02,03,04$, 05, 06, 07, 08, 09, OA, OB ... 0Z, followed by 10-1Z, 20-2Z, etc. The CID Number appears on each page of the manuscript. 


\section{Contents}

LIGHT MANAGEMENT IN PHOTOVOLTAICS

$1168106 \quad$ Ultra-thin photovoltaics for radiation-tolerant space power systems [11681-3]

1168108 Optoelectronic simulations for novel light management concepts in Cu(In,Ga)Se solar cells [11681-5]

PHOTOVOLTAIC TANDEMS WITH SILICON

$116810 C$ Development of dual junction GalnP/GaAs solar cells for high-performance concentrator photovoltaic quad-junction III-V/IV [1 1681-9]

ADVANCES IN CHARACTERIZATION OF PHOTOVOLTAIC DEVICES

$11681 \mathrm{OE} \quad$ Revealing micro-scale doping variations in thin-films via simultaneous luminescence and current collection measurements [11681-11]

11681 OF 4D-photoluminescence microscope based on single pixel imaging for characterization of semiconductors [11681-12]

MODELING AND SIMULATION OF ADVANCED PHOTOVOLTAIC CONCEPTS AND DEVICES

11681 OK High collection uniformity three-dimensional V-trough concentrators [11681-18]

QUANTUM ENGINEERING AND CARRIER RELAXATION/RECOMBINATION CONTROL IN SOLAR CELLS

$116810 \mathrm{~N}$ Investigation of hot carrier thermalization mechanisms in quantum well structures [11681-21]

PHOTOVOLTAIC MODULES AND SYSTEMS

11681 OT Thermal modelling and simulation of crystalline silicon solar cells and modules [11681-27] 


\section{POSTER SESSION}

1168112 The electronic interaction between vertically coupled Stranski-Krastanov and submonolayer quantum dots: a detailed investigation of carrier transitions and correlation with improved NIR energy conversion efficiency [11681-35]

1168114 The optimal scattering structures for light-trapping in ultra-thin photovoltaic devices [1 1681-37] 